5. Lacy, R. C. \& Sherman, P. W. Am. Nat. 121, 489-512 (1983).

6. Erhart, E. M., Coelho, A. M. Jr \& Bramblett, C. A. Am. J. Primatol. 43, 147-157 (1997).

7. Fredrickson, W. T. \& Sackett, G. P. J. Comp. Psychol. 96, 29-34 (1984)

8. Welker, C., Schwibbe, M. H., Schäfer-Witt, C. \& Visalberghi, E. Folia Primatol. 49, 216-221 (1987)

9. Dasser, V. Anim. Behav. 36, 225-230 (1988).

10. de Waal, F. B. M. J. Comp. Psychol. 110, 147-154 (1996).

11. de Waal, F. B. M. Chimpanzee Politics: Power and Sex Among Apes (Jonathan Cape, London, 1982).

\section{The oldest fossil ascomycetes}

Ascomycetes are the largest group of true fungi, and characteristically produce their sexual spores in a sac-like structure called the ascus. They include medicinal agents (such as ergot), plant pathogens (Dutch elm disease is caused by an ascomycete) and yeasts used in fermentation. We have found the oldest ascomycetous fungi with flaskshaped ascocarps in thin-section preparations of the Lower Devonian (400 million years old) Rhynie chert of Aberdeenshire, Scotland ${ }^{1}$. This discovery has implications for dating the origin of this group of fungi, and underscores the diversity of fungal-plant interactions early in the colonization of the land.

The fossils occur as closed fruiting bodies (perithecia) scattered just beneath the epidermis in the upright stems and rhizomes of the early land plant Asteroxylon (Fig. 1a); a few ascocarps have been identified on the scale leaves of this plant. Each globose perithecium (Fig. 1b) is approximately $400 \mu \mathrm{m}$ in diameter and develops in the stomatal chamber beneath a pair of guard cells. At maturity, the perithecium has a slightly elongate neck through which the spores are released. The perithecium wall is constructed of two distinct layers of interwoven hyphae. Arising from the inner layer are numerous tightly packed, elongate asci (Fig. 1c), each up to $50 \mu \mathrm{m}$ long. The ascus wall is thin and appears to consist of a single layer. Some asci have a slight invagination that encircles the tip of the ascus, suggesting the presence of some structural modification for spore release.

Arising from the same layer as the asci are delicate, thread-like structures. These may represent some form of sterile hairs (paraphyses) or be the remains of asci that have discharged their spores. Sterile hairs (periphyses) line the neck canal of each perithecium. Each ascus contains 16, and
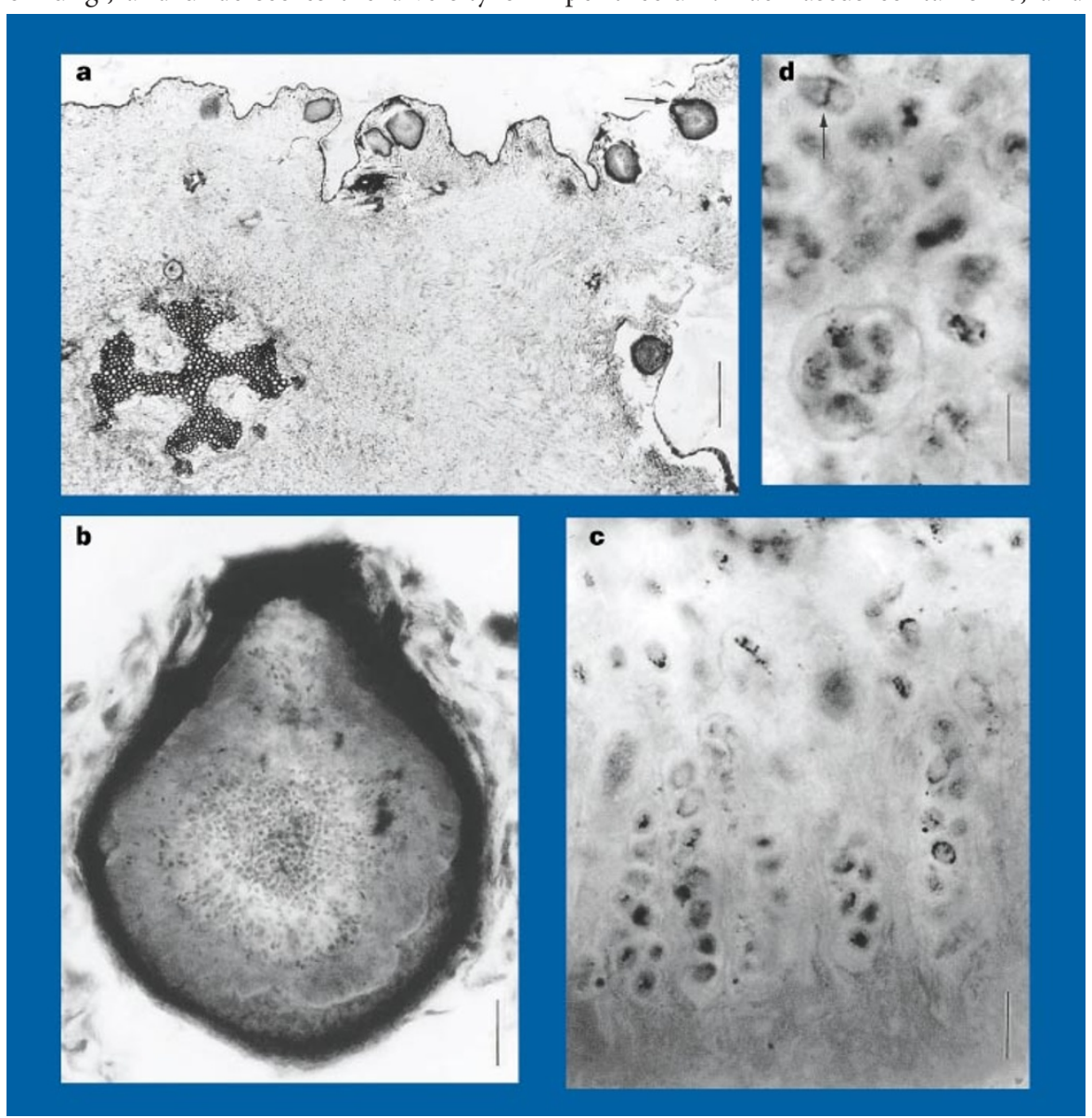

Figure 1 Lower Devonian ascomycete. a, Section of stem with ascocarps (arrow) in cortex. b, Perithecium in longitudinal section. c, Asci containing ascospores arising from inner wall of perithecium. d, Cross-section of ascus (lower left) with ascospores, some of which are bicelled (arrow). Scale bars: a, $500 \mu \mathrm{m} ; \mathbf{b}, 50 \mu \mathrm{m}$; c, $10 \mu \mathrm{m} ; \mathbf{d}, 20 \mu \mathrm{m}$. perhaps up to 32, elongate ascospores (Fig. 1c). Each ascospore is approximately $5 \mu \mathrm{m}$ long, and many are bicelled (Fig. 1d). In other regions along the stems, tufts of hyphae extend through the cuticle of Asteroxylon and produce chains of conidiospores (non-sexual spores) at their tips.

The fossil history of the Ascomycota is poorly understood ${ }^{2}$. Although chains of asexual spores and perforate hyphae recovered from digested rock samples of Silurian age have been interpreted as ascomycetes ${ }^{3}$, they may be modern contaminants or remains of some non-fungal group ${ }^{4}$. Molecular clock estimates have continued to push back in geological time the divergence of major fungal groups, with the most recent estimates suggesting that the basidiomycetes and ascomycetes diverged from one another about 500 million years ago ${ }^{5}$.

Comparative gene sequence data have identified three groups of Ascomycota: Archiascomycetes (unicellular yeast-like forms), Hemiascomycetes (yeasts) and Euascomycetes (filamentous forms). Euascomycetes are a monophyletic group that includes the pyrenomycetes ${ }^{6}$, which have elongate asci that arise as a single layer within a perithecium, and ascospores that are sometimes forcibly discharged at maturity. The most basal members of the Euascomycete group have not been resolved.

The Rhynie chert ascomycete fossils contain characters of the sexual stage of the fungus (such as perithecium, asci and ascospores) that are morphologically identical to those found in modern pyrenomycetes. They therefore provide the oldest evidence by approximately 250 million years of a major lineage of Euascomycetes with perithecial ascocarps. This is important because in some molecular trees the pyrenomycetes appear to be relatively recent compared with other ascomycetes. Because the characters in the Rhynie chert fossils are so well preserved, they can help to establish the sequence of phylogenetic events within this group. They therefore provide a means of calibrating the molecular clock data sets that are used to infer the phylogeny of fungal groups.

T. N. Taylor ${ }^{\star}$, H. Hass, H. Kerp $\dagger$

${ }^{*}$ Department of Ecology and Evolutionary Biology, University of Kansas, Lawrence,

Kansas 66045, USA

e-mail: ttaylor@falcon.cc.ukans.edu

$\dagger$ Geologische-Paläontologische Institut und Museum, Westfälische Wilhelms-Universität Münster, 4400 Münster, Germany

1. Taylor, T. N., Hass, H. \& Kerp, H. Am. J. Bot. 84, 992-1004 (1997).

2. Taylor, T. N. in Ascomycete Systematics (ed. Hawksworth, D. L.) 167-173 (Plenum, New York, 1994).

3. Sherwood-Pike, M. A. \& Gray, J. Lethaia 18, 1-20 (1985).

4. Berbee, M. L. \& Taylor, J. W. Can. J. Bot. 71, 1114-1127 (1993).

5. Berbee, M. L. \& Taylor, J. W. in Mycota (Springer, Berlin, in the press)

6. Alexopoulos, C. J., Mims, C. W. \& Blackwell, M. Introductory Mycology (Wiley, New York, 1996). 